\title{
THE GROWING ROLE OF CITIES AND THEIR NETWORKS IN THE INTERNATIONAL RELATIONS AND INTERNATIONAL SECURITY*
}

\author{
ROSNACA ROLA MIAST I ICH SIECI W STOSUNKACH \\ MIĘDZYNARODOWYCH ORAZ DLA BEZPIECZEŃSTWA \\ MIĘDZYNARODOWEGO
}

\author{
Agnieszka Szpak*
}

\begin{abstract}
- ABSTRACT
-

The author analyses the manifestations of cities' growing role for ensuring the national/international as well as environmental and human security. Cities of today increasingly participate in international relations - they internalize, implement and enforce international law, sometimes independently of their States' international legal obligations, for example when they pledge to implement human rights conventions or environmental law obligations that their own States did not pledge to fulfill. In this way they contribute to international peace and security. On the basis of those manifestations, the author attempts to explain the possible position of cities on the international plane and according to international law - whether they should be accorded greater autonomy or international legal personality. The
\end{abstract}

Autorka analizuje przejawy rosnącej roli miast dla zapewnienia bezpieczeństwa narodowego, międzynarodowego, a także ekologicznego i ludzkiego. Dzisiejsze miasta w coraz wyższym stopniu biorą udział w stosunkach międzynarodowych internalizują, wdrażają i egzekwują przestrzeganie prawa międzynarodowego, czasami niezależnie od międzynarodowych zobowiązań prawnych własnych państw, na przykład gdy zobowiązują się do wdrożenia konwencji z zakresu praw człowieka lub obowiązków z zakresu prawa ochrony środowiska, co do których ich własne państwa nie przyjęły zobowiązań. W ten sposób miasta przyczyniają się do pokoju i bezpieczeństwa międzynarodowego. Na podstawie tych przejawów aktywności miast autorka próbuje wyjaśnić ich pozycję na płaszczyźnie międzynarodowej

* Some parts of this article are also published in: A. Szpak (2015). Cities and Human Security. Torun International Studies, 1 (8), 119-133.

** Nicolaus Copernicus University in Toruń, Faculty of Political Sciences and International Studies. 
author also indicates that the role of cities in the area of different aspects of security is growing.

Keywords: cities, cities' networks, security, human security, environmental security i w świetle prawa międzynarodowego. Rozważa, czy miastom należy przyznać większą autonomię lub międzynarodową osobowość prawną. Autorka wskazuje również na rosnącą rolę miast w zakresie różnych aspektów bezpieczeństwa.

Słowa kluczowe: miasta, sieci miast, bezpieczeństwo, bezpieczeństwo ludzkie, bezpieczeństwo ekologiczne

\section{INTRODUCTION}

The Charter of European Cities and Towns: Towards Sustainability of 1994 begins with significant words: "We, European cities \& towns, signatories of this Charter, state that in the course of history, our towns have existed within and outlasted empires, nation states, and regimes and have survived as centres of social life, carriers of our economies, and guardians of culture, heritage and tradition. Along with families and neighbourhoods, towns have been the basic elements of our societies and states. Towns have been the centres of industry, craft, trade, education and government. We understand that our present urban lifestyle, in particular our patterns of division of labour and functions, land-use, transport, industrial production, agriculture, consumption, and leisure activities, and hence our standard of living, make us essentially responsible for many environmental problems humankind is facing" (para. I.1).

Cities have always been the centres of political, social, cultural and organizational innovations. City is the most important and probably the most innovative creation that emerged in the last ten thousand years (Bendyk, 2014a, p. 8). It is thanks to cities that the division of labour became possible. The latter increased its efficiency and contributed to the economic growth. Development of cities made it necessary to facilitate the transport, culminating in the current level of massive passenger air transport (Bendyk, 2014a, p. 9). Global cities or megacities, as they are sometimes called, "are places where a lot of wealth and power are concentrated, and which are in a position to take part in very influential global networks in a state of limited but real independence vis-á-vis their states and national governments" (Auby, 2011, p. 205). As stated in the UN Declaration on Cities and Other Human Settlements in the New Millennium, "[...] cities and towns are engines of growth contributing to the development of both rural and urban human settlements [...]" (point 2), and further, "[c]ities and towns hold 
the potential to maximize the benefits and to offset the negative consequences of globalization. Well-managed cities can provide an economic environment capable of generating employment opportunities, as well as offering a diversity of goods and services" (point 11).

On the other hand, States are too weak to handle the challenges of a global character such as climate change or economic globalization. In both of those cases, cities and their networks are better prepared to deal with such challenges. Cities possess intellectual, cultural and economic resources sufficient for those tasks. Big cities have almost everything that States have, except for such attributes as sovereignty and monopoly on the use of force (Bendyk, 2014a, p. 7). As D.A. French (2004, p. 61-62) points out, "[t]he nation State is changing; it is losing its inherent superiority amongst global entities and becoming just another actor on the international stage [...]. For many, the breakdown of artificial notions of sovereignty and the creation of new associations and networks - governmental, corporate and private - are a sign of significant and real developments in international relations. It signifies the end of the centralisation of political, socio-economic and, in some cases, military power by governments and the dispersion more widely of this authority. Others see the changing nature of the State as a positive step towards the creation of a global civil society, where the individual as the ultimate unit of law is more likely to find active expression and, equally important, protection".

F. Fukuyama (2005) indicates that today weak and failing States are the dominant ones. This is the result of a growing role of new social actors and new groups and of globalization that contributes to elimination of the barriers in the flow of people, goods and ideas. As such it also facilitates the proliferation of such dangerous and harmful phenomena as organized crime, international terrorism, or drug trafficking. In this context, one may affirm that States will not disappear but they will gradually cease to be the only structure of power. States are not omnipresent on the inside as well as outside. They cease to fulfill all of the social expectations that are carried with it by progress and internationalization of different spheres of social life (Bieleń, 2009, p. 47). Taking the processes of globalization into account it should be noted that every historical era influenced the shape of a State. In the ancient times there was no nation nor State at all, thus it is possible that they will disappear in the future (Bieleń, 2009, p. 47-48). But as K. Nowrot (1998-1999, p. 644) states, "[d]espite the variety of challenges to the predominant role of States in the international realm, the institution of the State as such will probably not become obsolete and wither away in the foresee- 
able future. The challenges by non-State actors to the position of nation-states, although obviously influential in some areas, can in general be regarded as being only sectoral ones, each in itself limited to a specific interest or segment of the society".

What is important, States are capable of self-transformation. Accordingly, the State does not die out but preserves its capacity to transform and adapt, for example adjusting to global market through privatizing public services such as medical service or telecommunications, or through deregulation in the meaning of eliminating barriers in the flow of financial resources (Bieleń, 2009, s. 49). Polish scholar and advisor to the Polish president on international affairs Roman Kuźniar (2003, p. 211) indicates that we can observe a far reaching weakening of the power of States over their territories and populations. The function of protecting the borders has also weakened as borders became more porous with regard to people, information and capital. It means that the room for maneuver for States in the face of new challenges has been narrowed down significantly. Governments are limited by the nets of different regulations, obligations and interdependencies. However, those nets should not be regarded as something negative that weakens States as these are simply State obligations, voluntarily contracted for the pursuance of common objectives and in the cooperation with other participants of the same network of obligations.

Still some classic functions of States such as in the spheres of military and national security are being strengthened. It is taking place especially after the September 11 attacks in the context of terrorist threat. As a result, the border control has increased, banking secrecy has been restricted, the possibilities of legal wiretapping have been broadened and international cooperation between internal security agencies of different States has been intensified (Anioł, 2002, p. 19).

Cities have been researched mostly in terms of its economic, technological, and social value and significance. Until about 2006 they had not been analyzed as legal entities with possibilities of taking actions on the international stage ${ }^{1}$. This state of affairs has changed today but still there is a need to research and wrote about cities as a fascinating phenomenon in many respects, also from the

1 In 2006 there were published such articles as: Y. Blank (2006). The City and the World. Columbia Journal of Transnational Law, 44 (3), 868-931; G.E. Frug, D.J. Barron, International Local Government Law. The Urban Lawyer, 38 (1), 1-63. 
point of view of different aspects of security, including national/international, environmental, social, and human security.

Section 2 of this article will deal with the manifestations of the activity of cities on the international stage such as internalizing and implementing international law (especially human rights law and environmental law), setting up offices of international relations or creating its own intelligence services. In Section 3, I will attempt to briefly outline the reasons for the growing role of cities in international relations. Section 4 will be devoted to explaining the legal status of cities in international law and their position in international relations - are they the subjects of international law, more and more powerful non-State actors? should they have such status, or greater autonomy? Finally, Section 5 will contain some concluding remarks.

\section{CITIES ON THE INTERNATIONAL STAGE}

References to cities in the legal texts or in the international law and international relations literature are extremely rare. But taking into account the fact that States are composed inter alia of cities and their significant role in many spheres, international law had to - in a way - deal with the challenges presented by cities. As G.E. Frug and D.J. Barron (2006, p. 13) indicate, "[a]longside the predominant focus on states, one finds two basic approaches to the city within international law. The first treats cities as being largely independent from any sovereign state and thus under the direct jurisdiction of the international community. The second treats cities as if they were indistinguishable components of their host countries, and thus without any meaningfully separate legal status".

One of the very rare examples of international law interest in cities is the status of the Free City of Danzig (Gdańsk) or the International City of Tangiers. The former was under the control of the League of Nations and the latter subjected to the control of multilateral body comprised of officials from various States. What is important is that those cities were not regarded as fully independent separate entities with legal personality (Blank, 2006, p. 886). G.E. Frug and D.J. Barron (2006, p. 14) conclude that " $t \mathrm{t}]$ he purpose of calling Tangiers an 'international' city and of designating Danzig a 'free' city was to highlight their independence from Morocco and Poland, respectively. They were not governed by a state in the way that cities usually are. The international community itself assumed that supervisory function. By recognizing these cities as legal entities, 
therefore, international law was not claiming jurisdiction over the domestic legal relationship between states and their cities. Instead, it was attempting to resolve territorial disputes between states by designating certain territory to be under the trusteeship of the international community. For that reason, these international cities paradoxically reinforced the invisibility of the city in international law. The city became visible so that it could be excised from its state". Y. Blank (2006, p. 886) adds that "[...] although Danzig was not a city in the contemporary sense of the word but rather a sui generis, free-standing city, the lesson that can be drawn from it is remarkable: If cities are to assume, once again, legal personhood in international law, they could very possibly resemble the Free City of Danzig".

Cities have been attempting to reach greater autonomy from the State. Accordingly, they have sought to become active players on the international arena. One of the strategies adopted includes forming international NGOs such as United Cities and Local Governments (UCLG), the most renown of such cities networks. This strategy aims at gaining visibility in international relations (Porras, 2008, p. 538-539). I.M. Porras (2008, p. 539) states that: "Basing their arguments on the democratic potential of cities and on the claim that city government is the level of government closest to the people and therefore most responsive to their needs, such groups have advocated for greater decentralization and autonomy for cities. The cities' assertion of the desirability of greater autonomy has been well received by the international community, which has embraced the city as an alternative interlocutor to the state. [...] Because cities, unlike traditional non-governmental organizations ('NGOs'), are able to lay claim to representative legitimacy, they have emerged as a favored actor within the umbrella of international civil society representatives".

As cities are becoming more and more active players on the international stage, there are more opportunities for their contacts with other cities across the border but also with international organizations of a governmental character. J. Nijman is of the opinion that direct and institutionalized relations between the city and global institutions will intensify. To illustrate this trend the Author focuses on Agenda 21 adopted by the UN Conference on Environment and Development held in Rio de Janeiro in 1992 (Nijman, 2011, p. 219). Chapter 28 of the Agenda 21, Local Authorities' Initiatives in Support of Agenda 21, states that "[b]ecause so many of the problems and solutions being addressed by Agenda 21 have their roots in local activities, the participation and cooperation of local authorities will be a determining factor in fulfilling its objectives. Local authorities construct, operate and maintain economic, social and environmental infra- 
structure, oversee planning processes, establish local environmental policies and regulations, and assist in implementing national and subnational environmental policies. As the level of governance closest to the people, they play a vital role in educating, mobilizing and responding to the public to promote sustainable development" (para. 28.1; Nijman, 2011, p. 219).

Since $1990^{\text {s }}$ the interaction and cooperation between cities and international organizations in the sphere of sustainable development, and consequently in the sphere of environmental security, has developed significantly (Nijman, 2011, p. 219-220). For example, UN Environment Programme (UNEP) cooperates with ICLEI (Local Governments for Sustainability) and C40 (C40 Cities Climate Leadership Group). UN-Habitat, ICLEI, IUCN's (International Union for Conservation of Nature) project Countdown 2010 (project completed), UNITAR (United Nations Institute for Training and Research), UNESCO, a Steering Group of Mayors, Secretariat of the Convention on Biological Diversity and UNEP engaged in the Global Partnership on the Cities and Biodiversity aimed at restricting the loss of biodiversity by 2010 (Nijman, 2011,p. 220; https://www.cbd.int/idb/2009/ about/celebration/global-partnership.shtml). According to the Partnership idea: "[w]hile cities are today part of the problem of the current unprecedented loss of biodiversity, they are also part of the solution. Indeed, they have a major role to play, as global change starts at the local level. Several leading cities and local authorities are actively involved in this battle for life on Earth and one of the ways they have chosen to spread the word about biodiversity loss is to celebrate the International Day for Biological Diversity, and to take this opportunity to inform their citizens about Invasive Alien Species" (https://www.cbd.int/idb/2009/about/ celebration/global-partnership.shtml).

Other examples of cooperation or participation of cities in the sphere of environmental security or them enforcing international law include: in 2010, during the World Mayors Summit on Climate in Mexico, 207 mayors of cities adopted the Global Cities Covenant on Climate - the Mexico City Pact (http:// www.iclei.org/climate-roadmap/advocacy/global-lg-events/2010-world-mayorssummit-on-climate-mexico-city.html). Organization C40 acts against the climate change by way of programmes promoting the use of bikes in cities and pedestrian streets (Barber, 2014, p. 22). As J. Nijman (2011, p. 214) indicates, "[c] ities are part of the problem of climate change, but also part of the solution". $75 \%$ of the global CO2 emissions is caused by cities. But as part of the solution cities have undertaken many programmes and actions to counteract environmental pollution, also in cooperation with other cities (Nijman, 2011, p. 214). 
For example, the Charter of European Cities and Towns: Towards Sustainability states that cities "shall give priority to ecologically sound means of transport (in particular walking, cycling, public transport) and make a combination of these means the centre of our planning efforts. Motorised individual means of urban transport ought to have the subsidiary function of facilitating access to local services and maintaining the economic activity of the city" (para. I.9). Similarly, the European Urban Charter II of 2008 provides that "ii]t is for us, European local elected representatives, to promote sustainable mobility policies which favour 'soft' means of travel such as walking and cycling as well as all forms of public transport" (http://www.coe.int/t/congress/texts/conventions/ conventions_en.asp?mytabsmenu $=6$ ). All of those activities definitely contribute to environmental security.

States are also losing functions and prerogatives that traditionally were performed by them at the central level, such as waging wars or country defence. It includes so called privatization of war and security, where many State prerogatives are assigned to private military and security companies/contractors (Joras, Schuster, 2008; Cameron, 2006). With regard to national/international security (as the two are inseparable today) more and more cities convene its own intelligence services. Mayor of New York, R. Giuliani started this trend when - after the September 11, 2001 attacks - he noticed that American State intelligence agencies did not work well. As a consequence, New York city removed its intelligence branch from Washington after the September 11 and redeployed it to twelve cities around the whole world. Today as well for example FBI does not cooperate with CIA and CIA does not cooperate with Interpol. Next New York mayor, M. Bloomberg sent his agents to Hong Kong, Jakarta, Rio de Janeiro, Tokyo, Moscow, and London. Police of those cities are also searching for terrorists and are in the possession of information that may be valuable and useful in New York. Since New York intelligence began to cooperate with cities from all over the world, no terrorist attack succeeded. And it did in Boston. According to B. Barber, Boston was relying on Washington. Moscow police warned FBI of attacks but Boston police never received those warnings. They were simply not transmitted to the Boston police (Zapędziliśmy się w ślepa uliczkę [interview with B. Barber], p. 110). If they had been participating in the antiterrorist network of cities they would have known about the threat of attack and could have prevented it. The above example demonstrates that national security becomes more and more the security/safety of cities (Zapędziliśmy się w ślepa uliczkę [interview with B. Barber], p. 110). This is the reason for the growing 
role of cities in the ensuring national and international security as those two are interconnected today.

In the context of international security one may mention the role of cities in "failed States". Taking into account all the characteristic features of the failed States, it must be concluded that they constitute a central security issue, especially after the September 11, 2001 attacks. As Y. Blank (2006, p. 918) put it, "[w]here states fail, localities might succeed". Blank (2006, p. 918-919) claims that "[1] ocally initiated adoption of international norms is often easier to achieve due to various reasons. First, homogeneity of values and preferences of the citizenry is more common in localities than it is in states. Second, it is often easier to mobilize residents in localities in order to achieve such reforms than it is to mobilize citizens nationwide. Third, local governments often allow for better participation and involvement of the public in government and thus enhance political passion and care for politics. Fourth, patriotism and nationalism are perhaps of lesser importance in localities and international influence is less threatening than it is for national entities". However, States are reluctant to accord cities such far reaching rights as they are afraid that it would amount to granting them some kind of a right to secede (Blank, 2006, p. 921). Nonetheless, in the context of "failed States" well-functioning cities may be the beginning of rebuilding of an equally well functioning State. Cities and States should cooperate in order to bring peace and stability in States or whole regions in crisis.

M. Byrne (2012, p. 113) suggests an alternative approach to a discourse on failed States. He indicates that whereas public order is absent in Somalia (as the most common example of a "failed State"), a social order is present, including in cities. Accordingly, even Somalia should not be regarded as a "failed State" as its society still exists and one might even say that it is functioning and still vibrant. And it is this society that can start rebuilding the State's infrastructure and public order. This process must be initiated and conducted from within the State of Somalia, whereas the international community may and should assist in this process, but definitely not take possession of it (Szpak, 2014, p. 255). Especially taking into account the society in "failed States" that is very often vibrant and able to organize itself and provide services, cities may be the nucleus from which States may begin to rebuild themselves. Cities may be the foundations for building a well-functioning State.

Cities also should cooperate in the sphere of cybersecurity and protect themselves against terrorist attacks on their critical infrastructure. For example, Los Angeles Cyber Intrusion Command Center is operated by the Los Angeles Police 
Department. It operates 24-hour-a-day and monitors online threats against the city (Goodwin, Nicolas, 2014, p. 16). "By creating a structured approach, thinking holistically about threats and vulnerabilities, and deploying strong practices to detect, mitigate, and communicate threats, a city can protect its citizens and safeguard its resources" (Goodwin, Nicolas, 2014, p. 21). By sharing their experience in this sphere cities may contribute to greater national security of their States. Naturally States will still be needed inter alia for securing the borders and currencies and ensuring respect for international treaties (Zapędziliśmy się w ślepa uliczke [interview with B. Barber], p. 110). But acting together, cities may become partners for States.

A great majority of cities have offices of international relations or international cooperation, for example Seattle, Atlanta, Goteborg, Kyoto (Frug, Barron, 2006, p. 29; Nijman, 2011, p. 214), New York (NY Mayor's Office for International Affairs) and many others. Another relevant instrument in the sphere of participation of cities in international relations sensu largo is the institution of twin towns or sister cities. It takes a form of legal and social agreement between cities from different States to promote cultural and commercial ties. The concept of town twinning was intended to foster friendship and understanding between different cultures and to encourage trade and tourism. Currently, the concept of sister towns has increasingly been used to form strategic international business links between member cities. Even the term "city diplomacy" was coined. It embraces direct contacts and mutual assistance between cities across the borders. For example Polish town Torun (that happens to be my town) cooperates with the following twin cities: Philadelphia (USA, since 1977), Göttingen (Germany, since 1978), Leiden (the Netherlands, since 1988), Hämeenlinnan (Finland, since 1989), Kaliningrad (Russia, since 1995), Čadca (Slovakia, since 1996), Swindon (UK, since 2003), Łuck (Ukraine, since 2008), Novo Mesto (Slovenia, since 2009) and Guilin (China, since 2010) (http://www.tmpt.torun.pl/twincities.html and http:// www.torun.pl/pl/miasto/samorzad/kontakty-partnerskie-i-miedzynarodowe/ miasta-blizniacze-torunia).

As has been indicated, cities form global networks. The most important city networks include: United Cities and Local Governments (http://www.uclg.org/), International Union of Local Authorities (http://web.mit.edu/urbanupgrading/ upgrading/resources/organizations/iula.html), World Association of Major Metropolises (http://www.metropolis.org/), National League of Cities (http:// www.nlc.org/), ICLEI (Local Governments for Sustainability, founded in 1990 as the International Council for Local Environmental Initiatives) (http://www.iclei. 
org/), C40 Cities (http://www.c40.org/), Eurocities (http://www.eurocities.eu/), U.S. Mayors Climate Protection Agreement (http://www.usmayors.org/climateprotection/agreement.htm), Megacities Foundation (http://www.megacitiesproject.org/), CityNet (http://citynet-ap.org/), and City Protocol (http://cityprotocol. org/). One should also mention Cities Alliance convened in 1999 by the World Bank and United Nations Human Settlements Programme (UN-Habitat) which "is a global partnership for urban poverty reduction and the promotion of the role of cities in sustainable development" (http://www.citiesalliance.org/). The most important of them is UCLG. The primary goal of the UCLG is " $\mathrm{t}] \mathrm{o}$ be the united voice and world advocate of democratic local self-government, promoting its values, objectives and interests, through cooperation between local governments, and within the wider international community" (http://www.uclg.org/ en/organisation/about). Its activities aim at increasing the role and influence of local government and its representative organizations in global governance and at becoming the main source of support for democratic, effective, innovative local government, close to the citizen (http://www.uclg.org/en/organisation/ about). In its Constitution of 2004 UCLG states that it is aware "that the traditional role of the State is profoundly affected by the above trends and that States cannot centrally manage and control the complex integrated cities and towns of today and tomorrow" (http://www.uclg.org/en/organisation/structure/ constitution-rules). The significance of global networks of cities is in the strengthening the position and influence of cities. It also "marks a break from the competitive order of the nation-states, as localities from all over the world manage to cooperate" (Blank, 2006, p. 923).

\section{ROOTS OF THE GROWING ROLE OF CITIES}

According to B. Barber, mayors are democratic, they act efficiently and they must be pragmatic. They are able to solve global problems just as they deal with local ones. The latter are caused by the growing helplessness of States and international system (Zapędziliśmy się w ślepa uliczkę [interview with B. Barber], p. 108). He is of the opinion that mayors - to a great extent - already rule the world. Mayors, alone or in cooperation with other mayors or entities, solve local and global problems. Cities can act more efficiently by associating into networks which they already do (Zapędziliśmy się w ślepa uliczkę [interview with B. Barber], p. 108). J.M. Coll (2015) points to five advantages for more efficient model of dealing 
with relevant global problems, namely by increasing the role of cities: 1 . Cities are more practical than ideological, 2 . Cities are more emotionally intelligent than nation-states, 3 . Cities bypass national sovereignty, 4 . Cities democratize the learning curve, and 5. Cities are global brands that attract the creative class. Those advantages clearly explain why the role of cities is growing.

J. Nijman (2011, p. 214) rightly claims that "[t]he self-conception of cities as global entities is not only caused by the impact of economic globalisation on the city, but also by the fact that the major global problems of our time (variations of human-political and ecological injustices) are often felt most urgently by the inhabitants of the world's cities". For example, global warming is global (as the name demonstrates), illnesses are global (such as AIDS, Ebola, bird flu, etc.), and corporations are also global. Very often those challenges must be met at the local level, in cities that are the gatherings of natural and legal persons as well as necessary infrastructure.

As I.M. Porras (2008, p. 553) claims, “[ $t$ ]he cities' ambitions have been met by an almost universal approval among international organizations. Indeed, it is possible to identify a convergence of interests between cities and international organizations and the forging of a common agenda. The main tenets of the common agenda are the promotion of greater local autonomy, decentralization, subsidiarity, and good governance. International organizations have endorsed localist claims and their agenda of increasing relative power vis-à-vis the state, but they have done so in large measure because they were already bent on a similar path under the aegis of "good governance»". International organizations became disappointed with States being often bureaucratic and corrupt. Many States are not democratic despite all the programmes and funds destined for this goal. This caused the shift in the attitude on the good governance and decentralization. Concentration of power in the hands of the State was regarded as a part of the problem, thus international organizations decided to invest in local governments that were perceived as offering "the greatest potential for democratic empowerment, accountability, flexibility, responsiveness to major stakeholders (including international organizations, public and private investors) and local knowledge. Furthermore, properly managed, it was thought, cities could deliver economic efficiencies to develop projects" (Porras, 2008, p. 553, 555). World Bank and other international organizations or agencies began to fund projects conducted at a local level. For example, the World Bank funding of urban projects is based on four conditions identified in its report Cities in Transition. World Bank Urban and Local Government Strategy: 1. Livability; 2. Competitive- 
ness; 3. Good governance and management; 4. Bankability (Cities in Transition, p. 8-12; Porras, 2008, p. 555). As I.M. Porras (2008, p. 559) indicates, “[p]erhaps because international organizations must always contend against states' criticism of their own democratic illegitimacy, or because states sometimes stand in the way of development agendas crafted for them by international organizations, many international organizations have adopted as their own the decentralization strategy of the cities". These are definitely root causes for the currently growing role of cities in international relations.

\section{GREATER AUTONOMY OR LEGAL PERSONALITY IN INTERNATIONAL LAW?}

The commonly accepted subjects of international law include States, international organizations, the Holly See, the Sovereign Order of Malta, insurgents, national liberation movements and, according to some scholars, individuals (Cassese, 2005, p. 71-150). As Y. Blank (2006, p. 871) points out, “[...] much has been written on the extension of international law over non-state actors such as individuals, minority groups, multinational corporations, and other civil society elements, localities have been overlooked. Hence, the role of international law in regulating one of the most important aspects of globalization - the changes that localities undergo as part of it and their role in bringing it about - was almost entirely ignored". Recently, however, much has been changed. As the above considerations indicate, the role of cities on the international stage is growing, also in the sphere traditionally and still reserved for States, namely national/ international security. As G.E. Frug and D.J. Barron (2006, p. 10) state, "[c]ities have entered into a new phase in history. Their orientation has become external rather than internal. Their associations have become global rather than domestic".

From the perspective of international law as well as internal law of every State, the city has been constructed from within a national legal order; it has been regarded as a part of the State. As I.M. Porras (2008, p. 546) notices, " $[t]$ he general consensus regarding the purely domestic character of the city-state relationship has been recently put into question by a series of developments that collectively have led to what we may call the internationalization of cities". One possibility to recognize some status of cities and their growing role with respect to international relations would be to give them broad autonomy. The UN Declaration on Cities and Other Human Settlements in the New Millennium clearly 
directs States to accord cities more autonomy in order for the latter to fully meet the expectations of its citizens and ensure their prosperity. This also refers to security. In point 40 the Declaration encourages "authorities within metropolitan areas to develop mechanisms and to foster, where appropriate, legal, financial, administrative, planning and coordination instruments, in order to achieve more equitable, ordered and functional cities", and in point 41 it further resolves "to build capacities and networks to enable all partners to play an effective role in shelter and human settlements development. The management of urbanization processes requires strong and accountable public institutions able to provide an effective framework in which everybody has access to basic services. Capacitybuilding needs to be directed towards, inter alia, supporting decentralization and participatory urban management processes. We also pledge to strengthen the institutions and legal frameworks that assist and allow broad-based participation in decision-making and in the implementation of human settlements strategies, policies and programmes" (The Local Rule: Decentralisation and Human Rights, p. 8).

The Local Rule: Decentralisation and Human Rights states that according to the proponents of decentralization, it "will improve the efficient provision of services, the quality of governance, economic development and efforts to alleviate poverty" (p. 8).

Some form of autonomy for localities was recognized for the first time in 1953 at the first General Assembly of the Council of European Municipalities in Versailles. At that time the European Charter of Municipal Liberties was adopted. It "reflected its proponents' commitment to rebuilding post-war Europe on the basis of strong local institutions enjoying a high degree of democratic autonomy" (Towards a World Charter of Local Self-Government, para. 7). Then in 1985, the European Charter of Local Self-Government was drafted (Towards a World Charter of Local Self-Government, para. 7). The Charter in its preamble states that self-government "entails the existence of local authorities endowed with democratically constituted decision-making bodies and possessing a wide degree of autonomy with regard to their responsibilities, the ways and means by which those responsibilities are exercised and the resources required for their fulfillment" (Towards a World Charter of Local Self-Government, para. 7). In the Draft World Charter of Local Self-Government of 1998 we read in Article 13 that "[1] ocal authorities shall have the right of recourse to judicial remedy in order to safeguard their autonomy and to ensure compliance with the laws which determine their functions and protect their interests" (Towards a World Charter 
of Local Self-Government, para. 7). As Y. Blank (2006, p. 905) sums up, "the vision in the Draft is of a minimal state, a back-up state that intervenes with local autonomy and local decision-making only in relatively rare cases, while the rule is local autonomy and subsidiarity".

When talking about international legal personality of cities one must admit that cities cannot conclude treaties and they do not have locus standi before International Court of Justice. They may not be members of international governmental organizations such as the UN but they surely may create and participate in NGOs. City networks could be regarded as NGOs. Cities do not maintain diplomatic relations with States or international organizations but - on the other hand - they conduct so called "city diplomacy" through their offices of international relations. As Y. Blank (2006, p. 885-886) indicates, there are “[...] several reasons for this tradition that lies at the heart of international law, some theoretical, others more pragmatic. The first, and perhaps the most obvious one is the traditional linkage between international law and the principle of sovereignty. The founding principle of international law is that states are sovereign within their territory and that international law is a self-imposed legal system to which states have to consent. Hence, only states should be the full subjects of international law, and they should be given the liberty to internally organize themselves, and be treated by external powers as unitary. [...] Second, the establishment of an efficient international regime depends on a limited and finite number of legally recognized international persons. [...] granting some localities full legal person would not only destabilize the UN structure and unbearably complicate international relations, but it would also encourage many localities to secede from their states in an attempt to acquire full international legal person. [...] Fourth, local governments are simply seen as integral parts of their states and it would therefore seem odd to even mention them as separate entities. Much like it would be redundant to mention explicitly the existence of the legislature, the executive, or any other state organ - let alone discuss the absurd idea of granting these state actors international legal personality - there is no need to mention localities, or debate their candidacy for an independent international personality".

Still, according to J. Nijman (2011, p. 221), in the future cities will increasingly implement and enforce international law and they will be doing that on their own initiative independent of State obligations. This trend or prognosis is already visible in the field of international human rights law and environmental law. In this way cities contribute to greater environmental, social and human security. 
Very often cities implement human rights conventions that their host States did not even ratify. For example, "the Child Friendly Cities Initiative (CFCI) is a global city network established to implement the United Nations Convention of the Rights of the Child directly in the participating cities. The UNESCO International Coalition of Cities against Racism and Discrimination aims to give direct effect to antiracism and anti-discrimination norms as included in international treaties, customary law (the prohibition of racial discrimination is ius cogens), and resolutions and declarations of IOs and their organs in the cities involved" (Nijman, 2011, p. 221-222). One of the initiatives undertaken independent of States obligations was that of Greg Nickels, the Mayor of Seattle, who in 2005 appealed to other cities to give effect to the Kyoto Protocol and reduce locally the level of greenhouse gases emissions. As the reaction was positive, it gave rise to a city network called the U.S. Mayors Climate Protection Agreement that comprises more than 1000 member-cities (Nijman, 2011, p. 222). “These cities give effect to the Kyoto norm through their local policies while the US as a state had not wished to be bound by the protocol. International law here plays a role in the self-identification of the city as a global actor which takes account of its responsibility with respect to climate change and takes the lead in the governance of one of the most urgent global challenges" (Nijman, 2011, p. 222). As is clear from the above remarks, cities often attempt to internalize international law - to include it in its local law, adopt its standards and enforce it. One may say that in a way international law is transposed into local law. Another example may be found in the sphere of human rights law. San Francisco (via Ordinance 1998 on the Local Implementation of the UN Convention on the Elimination of Discrimination Against Women) and Los Angeles have adopted the UN Convention on the Elimination of all Forms of Discrimination against Women (the U.S. did not ratify the Convention) and Salt Lake City and Seattle decided to fulfill the obligations flowing from the Kyoto Protocol that commits State Parties to reduce greenhouse gases emissions and in this way fights global warming (here again the U.S. did not ratify the Protocol) (Frug, Barron, 2006, p. 28; Nijman, 2011, p. 222-223). J. Nijman (2011, p. 224) also predicts that in the future cities will informally more strongly participate in international law-making. Cities are places where people live, work and spend their free time. For that reason it is important that human rights of the citizens as well as their security and safety are ensured. As the European Urban Charter II provides, cities and towns are "multigenerational, multicultural and multireligious places where people from all social backgrounds mingle on a daily basis. For urban society to develop 
fairly, mutual assistance between citizens, dialogue between groups, including inter-religious dialogue, and voluntary activity need to be promoted. We will continue our fight against financial and employment insecurity, exclusion and all forms of discrimination on grounds of social status, age, culture, religion, gender and disability" (European Urban Charter II). As is clearly visible, cities attempt to enforce human rights law on the local scale.

Cities also enter into agreements with other cities. For example, cities reached international (transnational) agreements over water resources even when no treaties between their states existed and without the consent of their states. For instance, in 1996 an agreement was signed between two municipalities, the Regional Council of Emek-Hefer, located on the coastal plain of Israel, and the municipality of Tul-Karem, in the Palestinian-controlled area of the West Bank. The agreement outlined the conditions of cooperation with reference to a polluted water basin that the two cities shared (Benvenisti, 2004, p. 140; Blank, 2006, p. 897-898). This activity may very well be placed in the area of environmental and social security.

Despite all those activities of cities in the realm of internalizing and enforcing international law which contribute to social, environmental and human security, one may argue that those actions and programmes are part of fulfilling obligations of States. As J. Nijman (2011, p. 222) rightly notes, "[t]he city is under an obligation to protect its urban population against violations of human rights as well as under an obligation to respect these rights. This is not an obligation independent from the state - it is an obligation stemming from international human rights obligations of states, of which cities are a part".

Apart from the above activities cities may, and actively do, oppose their States going to wars as for example did 165 cities when they passed a resolution opposing the U.S. war against Iraq (Frug, Barron, 2006, p. 28; Cities for Peace). In this way cities and also their networks may influence the foreign policy of its States. This protest was certainly aimed at preserving peace which is necessary for security; they are interconnected.

When talking about international legal personality J. Nijman (2011, p. 220) points to the Agreement of Cooperation between the United Nations Human Settlements Programme and United Cities and Local Governments from 2004 as an argument for some kind of legal personality of cities in international law. This agreement "aims to promote local autonomy and self-governance through decentralization played via UN-Habitat”. The Agreement - between a UN agency and an NGO - clearly proves that international organizations such as the UN 
or its specialized organizations recognize the cities network such as UCLG as an important partner. The Report of the Panel of Eminent Persons on United Nations-Civil Society Relations (so called Cardoso Report) of 2004 stated that the UN should regard UCLG "as an advisory body on governance matters" (We the Peoples: Civil Society, the United Nations and Global Governance. Report of the Panel of Eminent Persons on United Nations-Civil Society Relations, p. 20). Talking about UCLG, it has such prerogatives as nominating 50\% of the members of the UN Advisory Committee of Local Authorities (Nijman, 2011, p. 221). The latter was established in 2000 to enable local authorities to influence the work program of the UN-Habitat. It comprises of "selected mayors and representatives of local authority associations especially chosen on the basis of their local, national and international commitment to engage in the implementation of the Habitat Agenda" (Website of ICLEI). UCLG has also been accorded UN ECOSOC general consultative status since 1947. Other examples include Organization of Islamic Capitals and Cities (http://www.oicc.org/; general consultative status since 1995) and Academy for Mobilizing Rural-Urban Action Through Education (special consultative status since 2005) (http://csonet.org/index.php?menu=34). Consultative status definitely legitimizes such organizations and is a tool of their influencing decision-making and law-making at the UN.

The role and status of cities may be compared to the role of NGOs. The latter attempt to lobby for regulations that they approve. Cities similarly may try to influence States during their bilateral and multilateral negotiations. Naturally the position of cities and their clout will be strengthened if they cooperate within the framework of city networks (Nijman, 2011, p. 224). For example, during the 2009 Conference of Parties (COP) to the UN Framework Convention on Climate Change the ICLEI - network that had a formal observer status at the COP pressured States "for a strong post-Kyoto climate deal which would guarantee the involvement of cities as partners in the post-2012 regime" (Nijman, 2011, p. 224). Although the negotiations ended with a fiasco, at the next COP the States-parties "recognised the key role of cities and local governments - the city as 'governmental stakeholder' - play in global climate change governance" (Nijman, 2011, p. 224). Analogously to NGOs and individuals one may state that cities may be regarded as partial subjects of international law and their legal personality is highly restricted or even only emerging. It would be limited to activities undertaken within the city competence necessary to fulfill its functions and meet the social expectations of its citizens, including their security needs. For example, cities should be able to maintain international relations with 
subjects that recognize them and, for example, agree to conclude an international agreement. There is no doubt that such agreements would have to comply with the host State obligations. In order to accord cities some form of international legal personality, some form of a supervision of State organs would be necessary (Blank, 2006, p. 892). With reference to supervision, the European Outline Convention on Transfrontier Co-operation between Territorial Communities or Authorities provides that "any Contracting Party may, when signing the present Convention or in a later communication to the Secretary General of the Council of Europe, specify the authorities competent under its domestic law to exercise control or supervision with regard to the territorial communities and authorities concerned" (Art. 3 [5]).

Cities could also enter into agreements with other cities across the borders, which agreements after being authorized by their States could be recognized as part of international law (Blank, 2006, p. 898). On the other hand, cities already function vigorously on the international stage and are able to conclude informal agreements with other cities or enforce international legal obligations independent of States, sometimes even when their host State is not a party to a convention that the city wants to include in its internal law and implement. According to J. Nijman (2011, p. 228), cities will possess "soft international legal personality" similar to other non-State actors.

Whether one argues for international legal personality or greater autonomy for cities, one must notice a very interesting proposition to increase the role of cities on the international stage. B. Barber proposes to create a global parliament of mayors and city councilors (Barber, 2014, p. 391-400). In his opinion, the United Cities and Local Governments - the biggest and most influential organization that represents more than half of the world population - is a half way to the parliament (Barber, 2014, p. 21, 134). One might imagine such an organ being convened within international organizations such as the Council of Europe or the European Union (EU). Within the Council of Europe there already exists Congress of Local and Regional Authorities (http://www.coe.int/T/ Congress/Default_en.asp) and the EU includes as its organ the Committee of the Regions (http://europa.eu/about-eu/institutions-bodies/cor/index_en.htm). But it would be a little bit more difficult to imagine creating such an organ within the United Nations. Alternatively, such a parliament could take the form on a nongovernmental organization (NGO). The EU Committee of the Regions "gives regions and cities a formal say in EU law-making ensuring that the position and needs of regional and local authorities are respected. The European Commission, 
the Council of the EU and the European Parliament must consult the Committee when drawing up legislation on matters concerning local and regional government such as health, education, employment, social policy, economic and social cohesion, transport, energy and climate change. If this is not done, the Committee can bring a case before the Court of Justice" (http://europa.eu/ about-eu/institutions-bodies/cor/index_en.htm), which definitely strengthens its position and influence, despite its advisory role.

\section{CONCLUDING REMARKS}

Cities are energetic laboratories of social, political and cultural innovations. This is exemplified by participatory budgets, local currencies, barter exchange, time banks, consumer cooperatives, breakfast markets, media labs, or city bike systems (Bendyk, 2014b, p. 115). For example, Brazilian Porto Allegre in the beginning of $90^{\mathrm{s}}$ of the $20^{\text {th }}$ century introduced a participatory budget to include citizens into deciding about the budget's spending (Bendyk, 2014a, p. 8).

Cities may also be regarded as specific administrative entities and centres of making political decisions (Parysek, 2015, p. 29). Interdependency of cities makes them the appropriate building material to real order in the world (Barber, 2014, p. 176). According to B. Barber (2014, p. 183), the scale of the contemporary problems overwhelms States. Radical interdependency of globalised world in the $21^{\text {st }}$ century overwhelms States and pushes cities to the forefront. Decentralized planet, connected by the networks of cities and regions, already exists even though it is dominated by States. It includes a great variety of regional and non-State actors such as multinational corporations, global finance institutions, NGOs, and global social movements. Each of them is dealing in its own way with such relevant problems as climate change, social justice, public health, immigration, or child labour, traditionally falling under the State jurisdiction. It is impossible to ensure peace and security without the cooperation between States, international organizations, business community, and civil society (Barber, 2014, p. 360).

States are reluctant to accord cities international legal personality as this would threaten their sovereignty and potentially could lead to disintegration of States. As Y. Blank (2006, p. 890) claims, "[a]s long as there are states, and as long as states are the basic 'building blocks' of the international legal order, recognizing localities as legal persons threatens the sovereignty and supremacy 
of states and cannot happen without radically reshaping the current global order". Nevertheless, cities are subject to international law regulations, they internalize international law by including its standards in its local law, they finally implement and enforce it, sometimes independently of their States. Cities also form global networks that clearly strengthen their position on international stage (Blank, 2006, p. 892). Examples of cities implementing and enforcing international law referenced in this Article "point to an important development for the future: the city proceeds to implement international law directly and independently from the state" (Nijman, 2011, p. 223). Y. Blank (2006, p. 882-883) adds that "[...] the emergence of localities on the global stage marks a return to the age of independent and sovereign cities, albeit in a radically different global configuration. [...] Yet, [...] the current 'return' of cities should not be mistaken for going back in time to the European city-states of the Middle Ages or to the ancient Greek city-states. This re-emergence of cities is happening in a particular historical configuration in which states still possess huge legal, economic, social, and political power over localities. And the world, previously a highly abstract and vague concept, is becoming more tangible, supported by a community of internationalized human subjects, international norms, and institutions that claim to represent it". Based on that, States and cities should cooperate, support and in a way complement each other, especially taking into account the fact that national and international security are more and more the security of cities.

The problem of cities on the international stage, their growing role in many spheres of international cooperation, including human security (human rights law), environmental security and the national/international security as well as their status in international law, is indeed fascinating as fascinating are cities themselves. They are dynamic, energetic, innovative and constantly evolving. Various international or transboundary activities of cities are on the increase and they contribute to closer ties between people and nations and as a result to international peace and understanding. Among those activities one may list concluding agreements with other cities across the borders, internalizing and implementing human rights conventions and environmental law obligations that aim at sustainable devolvement. Cities also attempt to influence foreign policy of their States. By creating global networks their impact is becoming more and more visible. This article attempted to prove that, despite all the contrary views, cities do have some status in international law, that they are more and more powerful non-State actor on the international plane and their role and contribution to national/international as well as environmental and human security is growing. 


\section{REFERENCES:}

Anioł, W. (2002). Państwo postsuwerenne? Rozproszenie władzy w środowisku międzynarodowym. Sprawy Międzynarodowe 4, 5-26.

Auby J.-B. (2011). Mega-Cities, Glocalisation and the Law of the Future. In: S. Muller, S. Zouridis, M. Frishman, L. Kistemaker (eds.), The Law of the Future and the Future of Law (p. 203-212). Oslo: Torkel Opsahl Academic EPublisher.

Barber, B. (2014). Gdyby burmistrzowie rzadzili światem. Dysfunkcyjne kraje, rozkwitajace miasta. Warszawa: Wydawnictwo Muza.

Bendyk, E. (2014a). Widok z okna. Miasta i ludzie. Polityka. Wydanie specjalne 10, 6-8.

Bendyk, E. (2014b). Na rozstaju dróg, Miasta i ludzie. Polityka. Wydanie specjalne 10, 111-115.

Benvenisti, E. (2004). Sharing Transboundary Resources. International Law and Optimal Resource Use. Cambridge: Cambridge University Press.

Bieleń, S. (2009). Państwa w stanie kryzysu i upadku? In: M. Sułek, J. Symonides (eds.), Państwo $w$ teorii i praktyce stosunków międzynarodowych (p. 45-64). Warszawa: Wydawnictwo Uniwersytetu Warszawskiego.

Blank, Y. (2006). The City and the World. Columbia Journal of Transnational Law, 44 (3), 868-931.

Byrne, M. (2012). The Failed State and Failed State-Building: How Can a Move Away From the Failed State Discourse Inform Development in Somalia? Birkbeck Law Review, 1 (1), 111-134.

Cameron, L. (2006). Private Military Companies: Their Status under International Humanitarian Law and its Impact on Their Regulation. International Review of the Red Cross 863, 573-598.

Cassese, A. (2005). International Law. Second Edition. Oxford: Oxford University Press.

Charter of European Cities and Towns Towards Sustainability. Retrieved from http:// ec.europa.eu/environment/urban/pdf/aalborg_charter.pdf.

Cities for Peace. Retrieved from: http://www.ips-dc.org/projects/cities-for-peace/.

Cities in Transition: World Bank Urban and Local Government Strategy. Retrieved from: siteresources.worldbank.org/INTINFNETWORK/Resources/urban.pdf.

Coll, J.M. (2015). Cities Emerging Soft Power: 5 Key Advantages for Improved Global Governance. Retrieved from: http://isnblog.ethz.ch/technology/cities-emergingsoft-power-5-key-advantages-for-improved-global-governance.

Constitution of the World Organisation of United Cities and Local Governments, 2004. Retrieved from: http://www.uclg.org/en/organisation/structure/constitution-rules.

Declaration on Cities and Other Human Settlements in the New Millennium (S-25/2, 9 June 2001). Retrieved from: http://www.un.org/documents/instruments/ docs_en.asp.

European Urban Charter II. Retrieved from: http://www.coe.int/t/congress/texts/ conventions/conventions_en.asp?mytabsmenu $=6$.

French, D.A. (2004). The Role of the State and International Organisations in Reconciling Sustainable Development and Globalisation. In: N. Schrijver, F. Weiss (eds.), 
International Law and Sustainable Development. Principles and Practice (p. 53-71). Leiden/Boston: Martinus Nijhoff Publishers.

Frug, G.E., Barron, D.J. (2006). International Local Government Law. The Urban Lawyer, $38(1), 1-63$.

Fukuyama, F. (2005). Budowanie państwa. Władza i ład międzynarodowy w XXI wieku. Poznań: Wydawnictwo Rebis.

Global Partnership on Cities and Biodiversity and the International Day for Biological Diversity 2009. Retrieved from: https://www.cbd.int/idb/2009/about/celebration/ global-partnership.shtml.

Goodwin, C.F., Nicolas, J.P. (2014). Developing a City Strategy for Cybersecurity. A Sevenstep Guide for Local Governments. Retrieved from: http://download.microsoft. com/download/1/B/3/1B3C6BE3-8FA4-40BD-9BD6-640FD2F1F648/City\%20 Strategy\%20for\%20Cybersecurity.pdf.

Joras, U., Schuster, A. (eds.). (2008). Working Paper. Private Security Companies and Local Populations. An Exploratory Study of Afghanistan and Angola. Retrieved from: www.swisspeace.ch/fileadmin/user.../WP1_2008.pdf.

Kuźniar, R. (2003). Niebezpieczeństwa nowego paradygmatu bezpieczeństwa. In: R. Kuźniar, Z. Lachowski (eds.), Bezpieczeństwo międzynarodowe czasu przemian. Zagrożenia - Koncepcje - Instytucje (p. 209-227). Warszawa: Polski Instytut Spraw Międzynarodowych.

Nijman, J. (2011). The Future of the City and the International Law of the Future. In: S. Muller, S. Zouridis, M. Frishman, L. Kistemaker (eds.), The Law of the Future and the Future of Law (p. 213-229). Oslo: Torkel Opsahl Academic EPublisher.

Nowrot, K. (1998-1999). Legal Consequences of Globalization: The Status of NonGovernmental Organizations Under International Law. Indiana Journal of Global Legal Studies, 6 (2), 579-654.

NY Mayor's Office for International Affairs. Retrieved from: http://www.nyc.gov/html/ ia/html/home/home.shtml.

Official List of All NGOs in Consultative Status with ECOSOC, as of 1 September 2014. Retrieved from: http://csonet.org/index.php?menu=34.

Parysek, J.J. (2015). Miasto w ujęciu systemowym. Ruch Prawniczy, Ekonomiczny i Socjologiczny. Problemy rozwoju współczesnego miasta, 77 (1), 27-53.

Porras, I.M. (2008). The City and International Law: in Pursuit of Sustainable Development. Fordham Urban Law Journal, 36 (3), 538-601.

Szpak, A. (2014). What to Do With Failed States - a Quest for a Solution from the Inside. Chinese Journal of International Law, 13 (2), 251-258.

The Local Rule: Decentralisation and Human Rights. International Council on Human Rights Policy (2002). Retrieved from: http://papers.ssrn.com/sol3/papers. cfm?abstract_id=1551231. Toruń Twin Cities. Retrieved from: http://www.tmpt. torun.pl/twincities.html and http://www.torun.pl/pl/miasto/samorzad/kontaktypartnerskie-i-miedzynarodowe/miasta-blizniacze-torunia.

Towards a World Charter of Local Self-Government. Retrieved from: http://www.gdrc. org/u-gov/charter.html. 
United Nations Conference on Environment \& Development, Rio de Janerio, Brazil, 3 to 14 June 1992 AGENDA 21. Retrieved from: https://sustainabledevelopment.un.org/ content/documents/Agenda21.pdf.

We the Peoples: Civil Society, the United Nations and Global Governance. Report of the Panel of Eminent Persons on United Nations-Civil Society Relations. Retrieved from: http://www.un-ngls.org/orf/UNreform.htm.

World Mayors Summit on Climate - Mayors Push for Hope after Copenhagen. Retrieved from: http://www.iclei.org/climate-roadmap/advocacy/global-lg-events/2010world-mayors-summit-on-climate-mexico-city.html.

Zapędziliśmy się w ślepą uliczkę [interview with B. Barber]. (2014). Miasta i ludzie. Polityka. Wydanie specjalne 10, 107-110. 